Research, part of a Special Feature on Resilience and Vulnerability of Arid and Semi-Arid Social Ecological Systems

\title{
Socioeconomics, Policy, or Climate Change: What is Driving Vulnerability in Southern Portugal?
}

\author{
$\underline{\text { María A. Máñez Costa }}^{1}, \underline{\text { Eddy J. Moors }}^{2}$, and Evan D. G. Fraser ${ }^{3}$
}

\begin{abstract}
Although climate change models project that communities in southern Europe may be exposed to increasing drought in coming years, relatively little is known about how socioeconomic factors will exacerbate or reduce this problem. We assess how socioeconomic and policy changes have affected drought vulnerability in the Alentejo region of southern Portugal, where EU agricultural policy and the construction of a major dam have resulted in a shift from a land-extensive mixed agricultural system to the intensive production of irrigated grapes and olives. Following a dynamic systems approach, we use both published socioeconomic data and stakeholder interviews to present a narrative account of how this transition has increased the region's vulnerability to drought. To explore the assumptions made in the narrative, and to present different possible future scenarios, we create a dynamic systems model, the results of which suggest that socioeconomic drivers will play a more important role than projected rainfall changes in increasing vulnerability in the future.
\end{abstract}

Key Words: climate change; drought; Portugal; system dynamics modeling; vulnerability

\section{INTRODUCTION}

Planning and managing climate-related risks such as droughts presupposes that such events are well defined, anticipated, and discernible to all. This is an important assumption, particularly for farmers, because land-use decisions such as which crops to produce or what infrastructure to develop are usually made for economic reasons, months or even years before a drought appears, and the implications of such decisions may not be easily changed during times when water is scarce. Compounding this problem is the fact that long-range weather forecasting is still in its infancy, and significant uncertainty exists in the seasonal predictions needed to forecast the beginning and end of droughts (Rodwell and Doblas-Reyes 2006, Semenov and Doblas-Reyes 2007, Bechtold et al. 2008). This may explain why planning for droughts has received less attention than it deserves, and research is needed on adaptive-management strategies to reduce the impacts of droughts on rural livelihoods and natural resources.
Here, we study the semiarid Alentejo region in southern Portugal (see Appendix 1) and analyze whether socioeconomic factors have affected this social-ecological system's vulnerability to drought over recent decades. To do this, we follow Fraser (2007), who identifies climate vulnerability as occurring in cases where being exposed to a relatively small environmental shock, which in this case is a fairly minor meteorological drought, has a disproportionately large impact on livelihoods. In particular, we hypothesize that changes in the environmental, social, and institutional conditions of the study region, that is, changes that are themselves a response to larger-scale socioeconomic and political forces, will influence the region's vulnerability to new rainfall patterns. To explore these issues, we focus on three interrelated factors: (1) how changes to agroecological conditions have affected the extent to which the ecosystem can remain productive under changing climatic conditions; (2) how changes to the economy of local communities have affected people's ability to adapt to changing climatic conditions; and (3) how changes to the institutions present in the study 
region affect their ability to help manage climaterelated problems. In this third part of the analysis, we follow Ostrom (1990), who focuses on those formal and informal social structures that affect how communities govern common-pool resources such as water.

\section{LITERATURE ON ASSESSING VULNERABILITY}

Coping with, or adapting to, extreme climatic events involves both biophysical and socioeconomic factors. Therefore, a region's vulnerability depends not only on it being exposed to increasing problematic climatic events, but also on its environmental and social characteristics that will affect the impact of the anomalous weather. Recently, a number of interdisciplinary studies on vulnerability have tried to capture the complexities of such social-ecological systems (Adger 1999, Moss et al. 2000, O'Brien and Leichenko 2000, Alcamo et al. 2001, Heitzmann et al. 2002, Polsky et al. 2003, Turner et al. 2003, Adger 2006). However, in virtually all of these cases, it has proven difficult to apply the concepts of vulnerability to empirical cases because appropriate methods are lacking (Acosta-Michlik 2005). Therefore, further case-study-based research is required to advance these debates.

More specifically, vulnerability assessments have also been carried out at a range of scales using quantitative tools (e.g., Hurd et al. 1999, Vörösmarty et al. 2000). However, without a universally accepted "vulnerability measure," such analyses are usually based on fairly rigid and predetermined sets of indicators. For example, the vulnerability of people or ecosystems to water stress is often expressed in terms of hydrological variables such as the ratio between the supply and demand for water in a given region (Vörösmarty et al. 2000). Some indicator-based systems also take into account institutional characteristics (Hurd et al. 1999) or focus on ecological, social, and/or economic factors to incorporate measures of system sensitivity and adaptive capacity (Sullivan et al. 2002). In contrast, Simelton et al. (2009) presents an alternative indicator-based approach using statistical methods to identify the socioeconomic characteristics of vulnerability. Similarly, Brooks et al. (2005) use national-scale data and statistical methods to identify and weigh indicators of vulnerability and adaptive capacity. The value of these quantitative studies is that they provide an overview of vulnerability on a large scale, thus allowing comparisons between among regions and even continents. However, these overviews only consider a limited number of factors associated with vulnerability such as the relationship between drought and rice harvests (Simelton et al. 2009), or system characteristics and/or coping strategies (Sullivan et al. 2002).

In contrast with these quantitative studies are more qualitative, smaller-scale, and often participatory, vulnerability assessments. For example, Smit and Wandel (2006) involve the active participation of a range of stakeholders to ensure that information is collected on topics relevant to the community. Turner et al. (2003) advocate "place-based" vulnerability assessments and propose to analyze human and biophysical interactions as spatially continuous where one scale is nested within others. Cumming et al.'s (2006) findings are similar in that they show how coupled social-ecological systems have their own dynamics that are influenced by spatial, temporal, and functional scales. Without specifically addressing scale, Folke et al. (1998) also describe the mismatch between institutions and the ecological resources they are managing. This mismatch is explicitly addressed by Kinzig et al. (2006), who use four key case studies to argue that there are three domains (ecological, social, and economic) and three spatial scales (small $=$ patch, medium $=$ farm and large $=$ region) that must be considered when assessing a system's resilience. A regime shift or drastic change in any of the domains, or at any of the scales, may trigger changes in other domains and at other scales.

From this short synopsis of the vulnerability literature, it is clear that any assessment of vulnerability to climate change needs to explicitly address social, institutional, and biological factors, each of which operate on different scales. In particular, it is necessary to capture how issues at the institutional level may drive changes in land use and how this may increase vulnerability at a range of scales. In response to these complexities, our goal here is to explore whether climatic, socioeconomic, demographic, land use, and policy factors have increased or decreased vulnerability to environmental shocks in the Alentejo region in southern Portugal. Here, we chose the phenomenon "drought" as an extreme climate event and understand it as a persistent period in which a particular region experiences a decline in rainfall and/or increase in 
temperature, where these changes translate into a yearly water deficit. This was experienced in the Alentejo in 1999, 2002 and 2005 (Gouveia et al. 2009).

Drawing on the literature mentioned, three linked assessments were conducted to show how vulnerability to drought has changed in the study region. The first explored how changes in the region's agroecology have affected the vulnerability to changes in rainfall. The second assessment explored how economic changes affected the ability of communities to adapt to rainfall changes. The third explored whether recent changes have affected local institutions' ability to help mitigate or manage drought-related problems. These assessments follow Fraser (2007) and Fraser et al. (2011), who argue that these three factors are useful in assessing vulnerability to climate change in that they can be heuristically depicted as the axes of a vulnerability space (see Fig. 1). In this vulnerability space, demographic, economic, or policy changes may cause changes over time along these three dimensions, thereby affecting the overall vulnerability of the system to climatic change. For example, the arrows in Fig. 1 show a hypothetical case where changes in the system have caused the system's agroecosystem to become more fragile ( $x$ axis) over three points in time (T1,T2, and T3), its communities to lose assets ( $y$-axis), and its institutions to lose the capacity to respond to a crisis (z-axis). If this sort of trajectory is observed in the real world, then it may be inferred that the system is becoming more vulnerable to climatic change such that relatively small climatic perturbations may cause significant problems.

\section{METHODS AND RESEARCH DESIGN}

We followed the research steps outlined in Fig. 2 to assess whether, and if so, how, policies and socioeconomic factors have affected vulnerability to drought in the study region. Appendix 2 provides details on those interviewed for this study.

\section{Phase 1}

Phase one of this project took place within the Aqu aStress project, a large European Union (EU) Sixth Framework project that involved a range of European and African partners who worked together to assess and evaluate water stress in a number of key regions. The first step was to analyze regional stakeholder groups in the Alentejo region of southern Portugal. To do this, we adapted the "stakeholder analysis for projects" approach and used a snowball sampling process (see Department for International Development 1995, Montgomery 1995, Howlett 2000). Through this process, we identified that key stakeholders included: smallscale end-users, development practitioners, policy makers, planners and administrators in government, commercial bodies, and nongovernmental organizations. From among these categories, 25 participants were chosen for face-to-face interviews (see Appendix 2). We also facilitated one participatory focus group in November 2007 where participants were asked to describe the "problem" in the area and where to focus research. During the focus group, participants were also asked to fill in questionnaires that consisted of questions on the following topics: (1) actual water/climate-related situation, (2) knowledge and perception of climate change, (3) understanding and perception of causes of the current situation, (4) existing, known, and desired mitigation options/ policies for droughts, (5) information on additional and missing stakeholders, and (6) knowledge of existing drought policies.

\section{Phase 2}

In phase two, we used the interview transcripts as well as background data to determine how and why the region was becoming more or less vulnerable to drought, and what the stakeholders perceived to be the causes of those changes. During this phase, we contrasted opinions expressed in the interviews with secondary data that was collected from a range of internal, local, or government sources (see Appendix 3). Where data was unavailable to test claims made during the interviews, we relied on expert knowledge of the extended AquaStress team to refine or refute interview data. We then synthesized these various types of information into a single narrative that accounted for land use and economic changes for the past three and a half decades (European Commission 1995, Pachauri and Reisinger 2007; see also Appendix 3). This narrative was then presented to experts of the project and refined to show how and why vulnerability has changed. While conducting this assessment, to explore the complex interactions and feedbacks described in the narrative, we built a causal-loop diagram, or conceptual model, of the system. For a full discussion and rationale of this approach, please see Fraser et al. 2011. 
Fig. 1. Vulnerability space build-up along three "meta" categories: (1) sensitivity of agroecosystems to water stress, (2) access to capital assets, and (3) institutional capacity to adapt to crises.

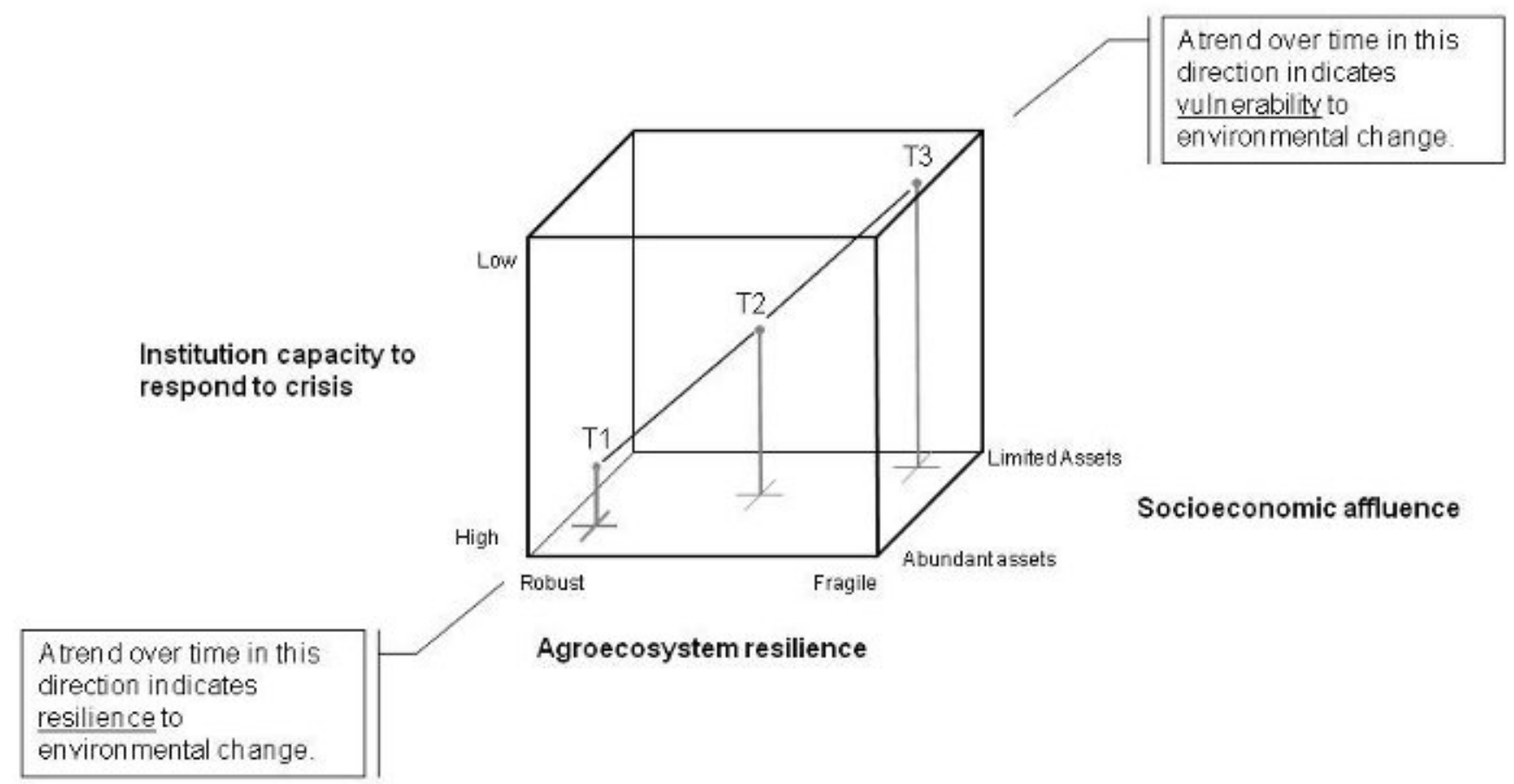

Note: $T 1, T 2$ and $T 3$ depict the different states in time of vulnerability to climate ch an ge for a hypothetical case.

\section{Phase 3}

In phase three, our goal was to explore the implications of our results for future vulnerability. It is important to note that, for regions such as the Alentejo where background data is limited, creating accurate predictive models is impossible. Nevertheless, it is possible to model the implications of different future scenarios as a way of challenging our understanding about how social-ecological systems work and identifying uncertainty. Therefore, the goal of this step was to use the data generated by the interviews as the basis for models that would allow us to explore how vulnerability might change under different scenarios. To do this, the nature of the relationships in the conceptual model were estimated in terms of their strength and direction (e.g., slope) and whether they were linear, exponential, or curvilinear (see Fraser et al. 2011 for a discussion about the merits and challenges of this approach). Although the basis for these estimates, that is, the information contained in the interview transcripts, was entirely qualitative, doing this meant that scenarios could be formally modeled, thus providing a means for evaluating the importance of the assumptions implicit in the narrative. As a result, these models are not intended to be predictive. Rather, the equations used in the model became tools to allow us to critically explore both the model itself and the assumptions made by the stakeholders who provided the information that led to the narrative in the first place. The models also allowed the simulation of "would-be worlds," enabling critical reflection on different pathways that vulnerability could take over time (Casti 1997). 
Fig. 2. Research steps.

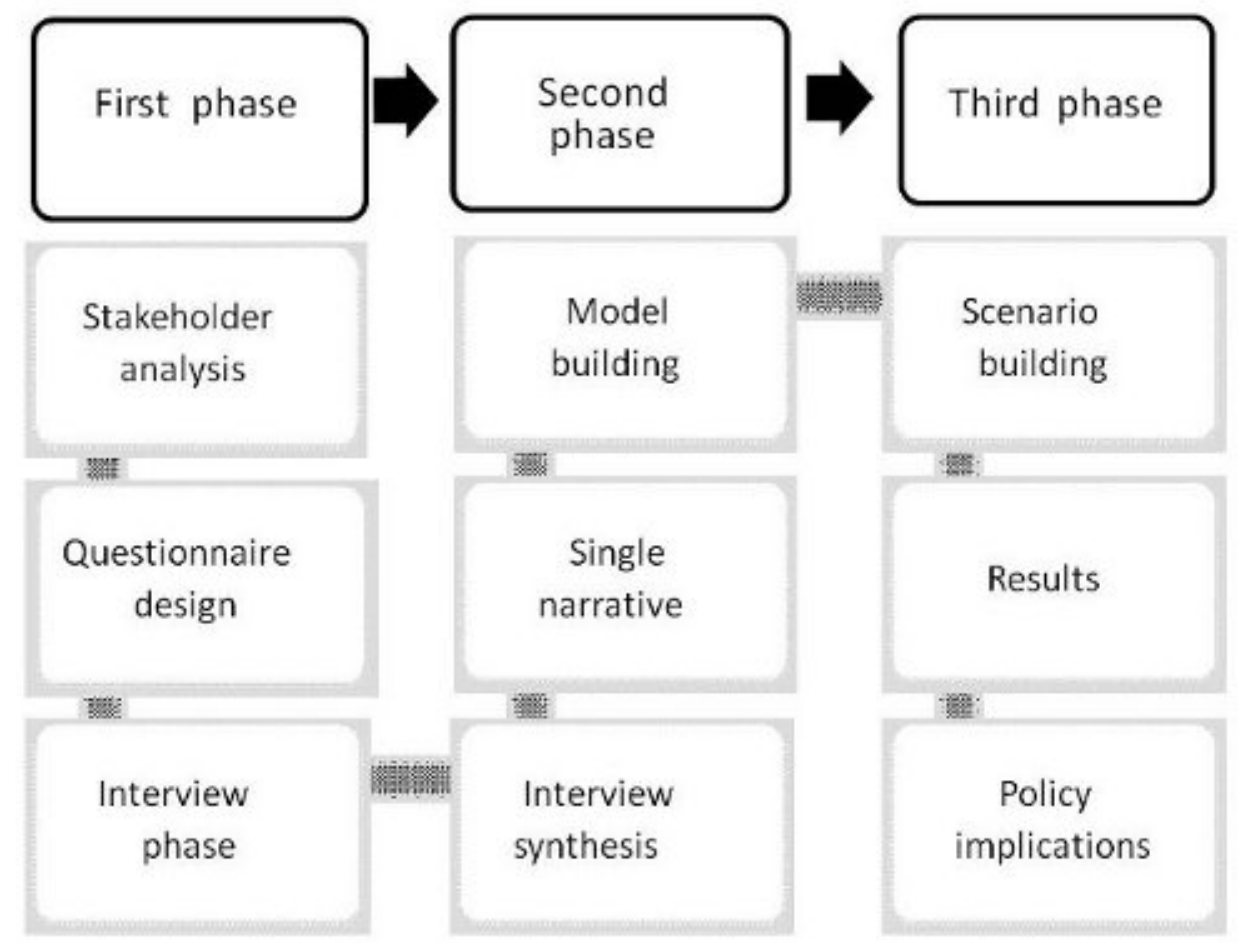

SYNTHESIS OF PHASE I AND II: ACCOUNTING FOR CHANGING VULNERABILITY TO DROUGHT

\section{Background Narrative}

The Alentejo region of southern Portugal (Fig. 3) is one of the poorest in the EU-15, and its population and economy are shrinking (do Ó and Roxo 2001). However, in recent decades, socioeconomic changes have resulted in new land uses that promised a new economic development path. Those changes have accelerated since Portugal's entrance into the EU in 1986 when Portugal became eligible for cereal subsidies and took up increasingly intensive cattle production (do Ó and Roxo 2001). European policy and the Program for the Development of Portuguese Agriculture (PEDAP) also led to intensified cropping systems that used more agrochemicals and mechanization. In Alentejo, old olive groves, orchards, and "montados" (a traditional land-use system made up of extensive pig production and cork oak (Quercus suber), used to produce wine corks) were replaced with irrigated cereals and other annual crops such as sunflower. Erosion increased, as did water and soil pollution (Seita-Coelho 2006).

This situation lasted until the common agricultural policy (CAP) reform of 1992, when cereal production was dropped as a priority. Combined with a crisis in livestock management (partly because of BSE), which had traditionally complemented cereal production, this led to a phase of agricultural intensification (Seita-Coelho 2006). Concurrently, reforestation policies became more attractive to old farmers without successors, and to landowners who had left the area or who for other reasons were no longer full-time farmers (PintoCorreia et al. 2004). After the latest round of CAP reforms in 2003, the policy and economic context changed again with the introduction of subsidies for olive-oil production and vineyards (see Fig. 4). The EU, as the leading world producer of olive oil, had a stake in supporting production. Since then, irrigated areas have expanded because of the new olive plantations and the montado system is again in decline. This has caused soil degradation due to deeper ploughing and higher stocking rates that impede natural regeneration (Pinto-Correia and 
Fig. 3. Map depicting (in gray) the Alentejo region of southern Portugal.

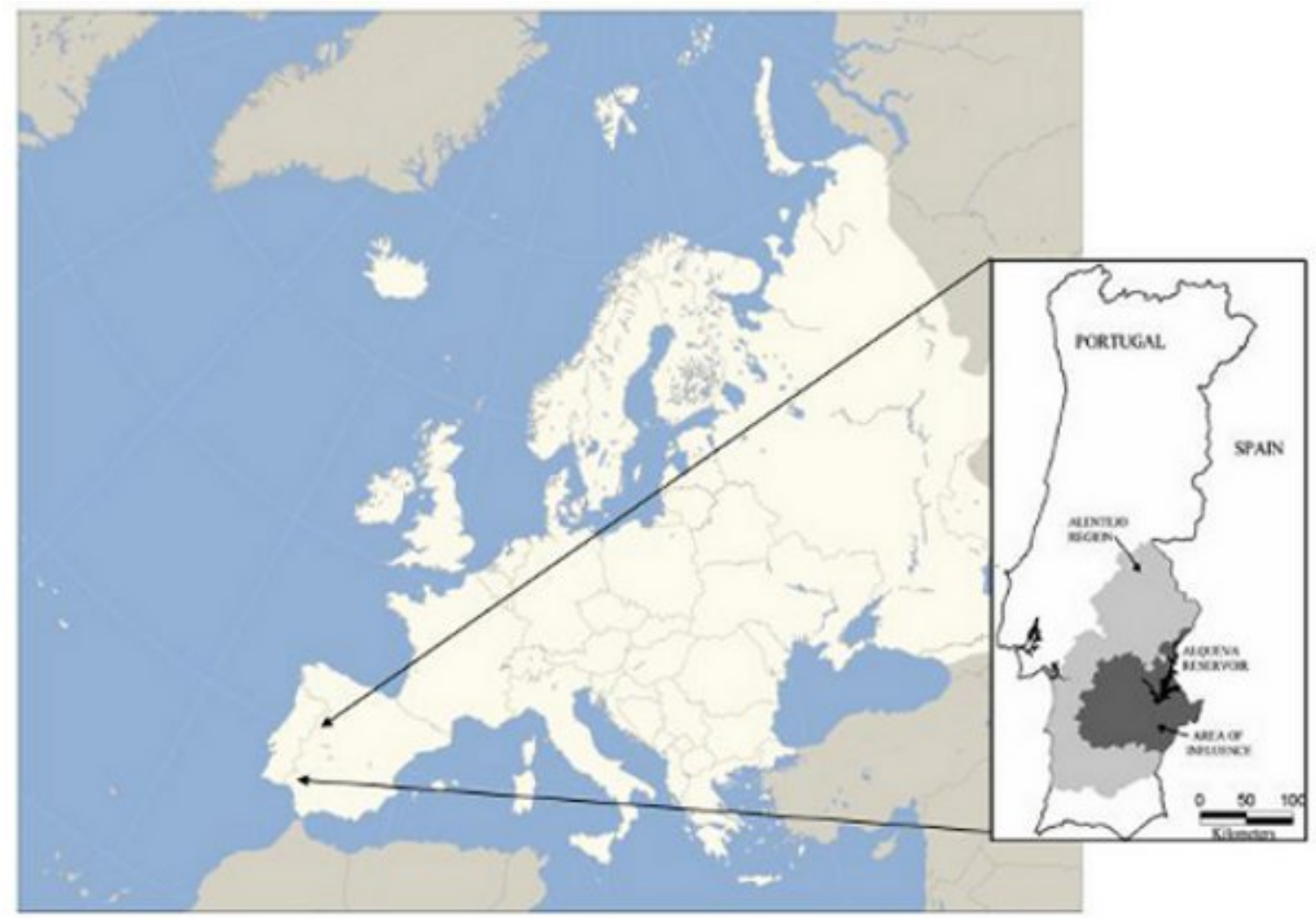

Source: AquaStress Project and Wikipedia.

Mascarenhas 1999, Seixas 2000). Figure 5 also depicts an agroecological shift from the traditional mixed montado landscape to olive orchards and irrigated crops. This is significant because although traditional olive groves require just $2,500 \mathrm{~m}^{3}$ of water per ha, irrigated fields need $>5,000 \mathrm{~m}^{3} / \mathrm{ha}$. Therefore, the interviewees suggested that Alentejo is now more dependent on water than ever before. This was seen by stakeholders as a problem because this semiarid region suffers from recurrent droughts. For example, a representative of a national NGO interviewed during this research said: "The need for more income has turned us blind. Almost everyone has invested in irrigation and has forgotten that rain and water are precious rare goods." Additionally, groundwater is reported to have become badly polluted through inadequate waste disposal as well as excessive fertilizer and pesticide use (Chambel et al. 2006, Castro 2008).
In terms of surface water, the Guadiana River is the main collector in the region and already experiences high annual variability (Hulme and Scheard 1999, Government of Portugal 2001, Gouveia et al. 2009). This has resulted in serious droughts in 1999, 2002, and 2005 (see Gouveia et al. 2009). To address this problem, the "Alqueva multipurpose project" was developed, involving building a dam to create a 250 $\mathrm{km}^{2}$ reservoir that is supposed to store enough water from wet years to cover a series of dry years. This construction, the largest dam project in the EU to date, was finished in 2002, and the reservoir had filled by 2006. However, stakeholders are concerned that the dam actually causes an incentive for farmers to establish more irrigation, and that this will accelerate the decline in traditional land management. The reservoir is currently underutilized, but as more land is linked with the reservoir, the pace of land-use conversion and water use may increase. As a result, some are concerned that these 
Fig. 4. Land distribution in the Alentejo region.

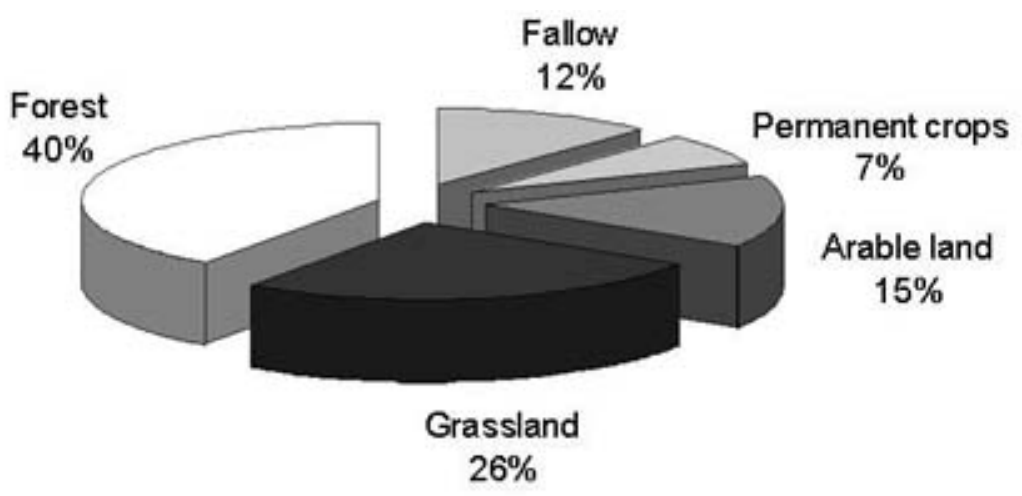

Source: European Commission 2005

changes have made the region the most sensitive area to drought and desertification in Portugal (Pimenta et al. 1997).

Other problems with the Alqueva were also mentioned during our interviews. In particular, (1) much of the infrastructure is still not yet in place, (2) there is a lack of basic research on the potential effects of the dam on the region's ecology and economy, and (3) the constant humidity caused by the dam's reservoir might create an opportunity for a fungal pathogen of the cork-oak tree to become established year-round and grow to epidemic levels, thus further undermining the montado system (Correia 1993, Pereira and Pires de Fonseca 2003, Pinto-Correia 1993, United Nations Educational, Scientific and Cultural Organization 2006, Van den Wyngaert et al. 2006). Therefore, from an agroecological perspective, the new system of irrigated crops with its greater water requirement and associated other ecological problems, has, in the opinions of the interviewees as well as the academic literature, created a land-use system that has become more vulnerable to climate change than in the past (Pereira and Pires de Fonseca 2003, Nunes et al. 2009).

From a socioeconomic perspective, the shift in land use not only means that the social-ecological system requires more water to operate, but also implies considerable on-farm specialization. Today, it is common that farm production involves a single commodity (e.g., grapes or olives) whereas, before, farm income was more diversified, based on a mixture of cereals, animal husbandry, and cork production. The expansion of olive fields has been significant, increasing from $18 \%$ of the total permanent crop area in 1995 to 62\% in 2007 (Food and Agriculture Organization 2007). Interviewees reported that the main reasons for changing to irrigated crops were: (1) the promise of a continuous water flow and an irrigation infrastructure coming from the Alqueva, and (2) the EU subsidies obtained for farm improvements (PEDAP program) and olive-oil production. This point was demonstrated by a farmer interviewed during this research: "Now we get more money from olive production than even before-you'd be an idiot not to change production." This was also raised in another manner by a representative of a farmers' association, who argued that European policy was far more influential than local policy in determining landmanagement decisions: "I don't know which new agrarian policies are in Portugal, but I know the EU policies very well. They are more important for us. If they change, our economy changes."

The Alqueva reservoir has been described by stakeholders as "deficient" in additional ways. For example, the interviewees reasoned that administrative extension services in the Alentejo are very limited in use because of a lack of qualified staff and cutbacks in local governmental programs. Local farmers' associations are almost the only source of information on policies, restrictions, and available support (Kosmas and Valsamis 2002) and according to stakeholders and experts, Portugal lacks an appropriate national plan for climate change 
Fig. 5. Conversion of montado (over the gray line) to olive orchards (under the gray line).

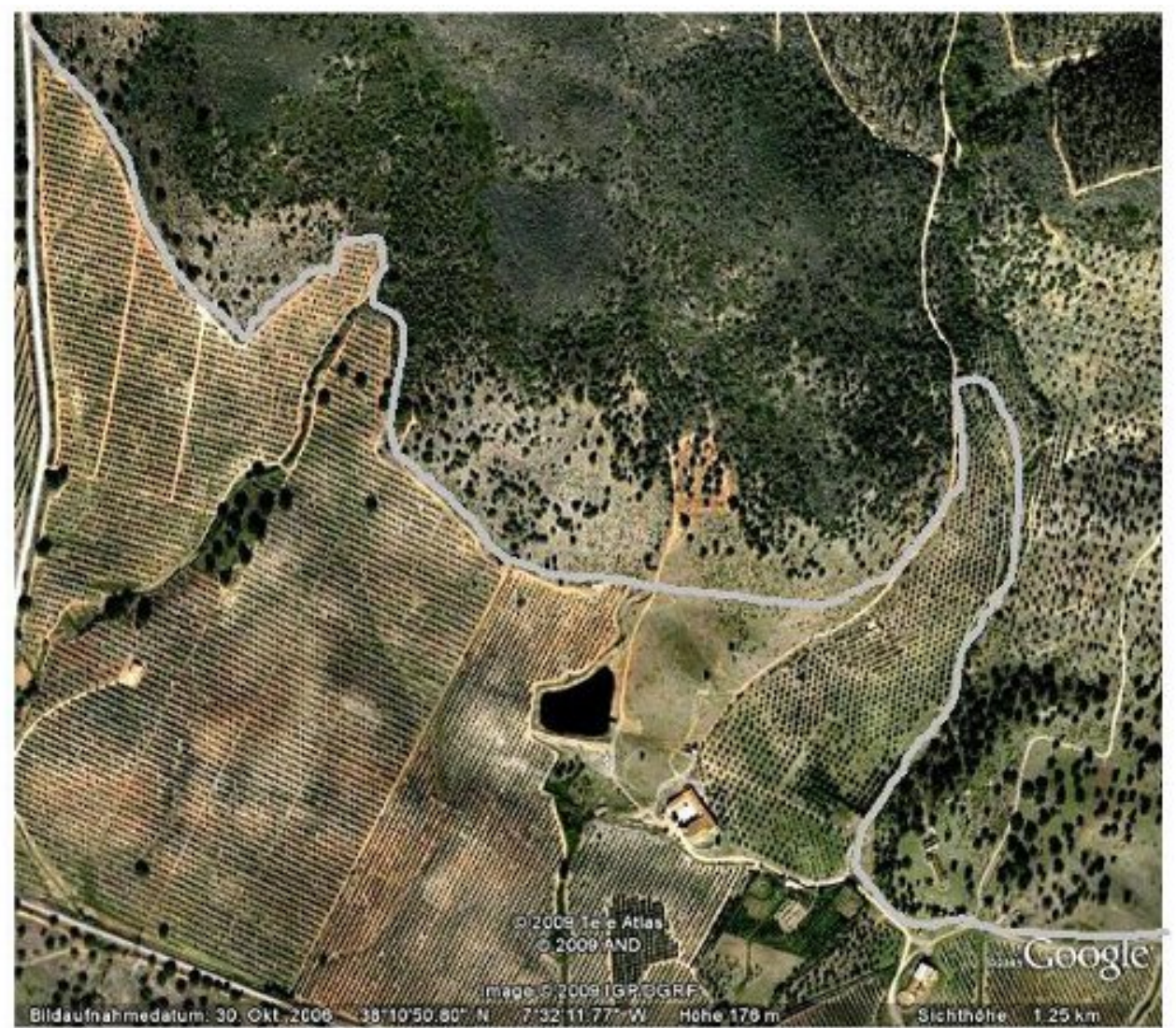

Source: Google Earth

adaptation and mitigation (e.g., for drought management). Although some alternative plans and policies do exist, many have never been applied, such as the National Environmental Policy Plan. On water and drought management, stakeholders reported that although there are water policies in place, many are overlapping and this causes administrative confusion. In particular, concern was raised about the municipality of Mértola, where six plans have overlapping authority on drought planning: (1) the municipal director's plan (administrative local authority), (2) the national water plan, (3) the Guadiana water-basin plan (water-basin territory), (4) the forestry sustainable development plan (administrative national territory); (5) the management plan for the Guadiana national park (conservation territory); and (6) the national action plan to combat desertification and drought (Van den Wyngaert et al. 2006). Together, this confusion of policies means that local formal institutions struggle to be effective in planning for drought (do Ó and Roxo 2001).

\section{Conceptual Model}

Three key economic, institutional and agroecological factors emerge from this narrative:

1. The change from the montado system to an irrigated agroecosystem after 2003 has meant that farming in the region requires more water than in the past, which makes the system more vulnerable to drought.

2. The socioeconomic drivers of this agroecological shift have reduced the diversity of local farmbased income sources, making livelihoods dependent on a small number of waterintensive crops. 
3. To a large extent, these changes have been driven by EU policy (e.g., CAP, PEDAP, EAGF, etc.). This has reduced the efficacy of local institutions to develop policies that would enhance climate resilience at the local scale.

We have heuristically illustrated these changes in agroecological resilience, access to assets at the community scale, and the capacity of relevant institutions to respond to a climate-related problem in Fig. 6. The figure shows how those three factors changed at four points in time: (1) Time 1 (T1) or the period circa 1974 when the Portuguese dictatorship ended, (2) Time 2 (T2), which marks Portugal's access to the European Economic Union in 1986 when the first European structural programs and agricultural subsidies started, (3) T3, representing 1992 when cereal subsidies were cut, and (4) T4, which is the present day as perceived by the stakeholders we interviewed.

In Fig. 6, we see that the trajectory of this region is toward the back, top right-hand corner, which suggests an increased vulnerability to drought, such that in the future, smaller droughts may have bigger impacts on the region's social-ecological system. This may be especially significant given that predictions from the Intergovernmental Panel on Climate Change (Bates et al. 2008) are that this region may experience more droughts in the future.

However, it is important to note that the changes in these three dimensions have not occurred on their own, nor are they isolated. For example, the Alqueva reservoir acts as a massive evaporation pan and this has increased year-round levels of humidity. Constant humidity means fungal pathogens of the cork oak have become established throughout the year and traditional farmers now regularly face epidemic levels of this problem. This means montado farms are less economically viable than in the past. Additionally, the montado system is also dependent on labor availability. As such, the viability of this system is linked to agricultural policies and nonfarm labor markets (such as tourism) that draw people out of agriculture. As these sectors of the economy have grown, the montado system has become less viable. Both of these drivers have increased the incentives for remaining farmers to convert farms to crops that require less labor.
To represent and better understand this complex social-ecological system, we developed a causalloop diagram as a basis for modeling, drawing on our interview transcripts, published data, and secondary sources (see Fig. 7 and Appendix 3). Then, we adapted a version of "system dynamic modeling" (Forrester 1961, Nordhaus 1992, Fiddaman 1995, Brans et al. 1998, Forrester 2000, Stave 2002, Martínez Fernández and Esteve Selma 2004) for representing and modeling the trends outlined in Fig. 6.

\section{SYNTHESIS OF PHASE III: SCENARIOS AND POLICY IMPLICATIONS}

In the final phase of this research, we used information gathered from the interviewees along with climate predictions from the IPCC report to identify three possible future scenarios for the region: (1) an increase in the subsidy for olive production; (2) a decrease in subsidy for olive production; and (3) an increase in droughts. According to the stakeholders, each of these three scenarios is likely to have an effect on the following six factors:

1. farm income;

2. the total population in the region as well as the population engaged in agriculture;

3. water pollution;

4. water availability;

5. the amount of irrigated land; and

6. the land area remaining under the traditional montado system.

We then used the interview data, expert opinion, and background data to infer how these six factors might change under each scenario, and modeled the implications of how these changes would affect these three axes of vulnerability, as outlined in Fig. 6 . The scenarios, along with a comparison in terms of their impacts on the six factors, are presented in Fig. 8 and Fig. 9. Although the predictive capacity of this modeling approach is extremely limited, this exercise was done to provide insights on how different factors might increase or reduce the vulnerability of the region in the future. 
Fig. 6. Vulnerability analysis suggesting that over time, this rural economy and land-use system has become more vulnerable to water stress (indicated by the movement to the top, right, back corner of the figure) such that smaller droughts will have larger impacts on the local economy.

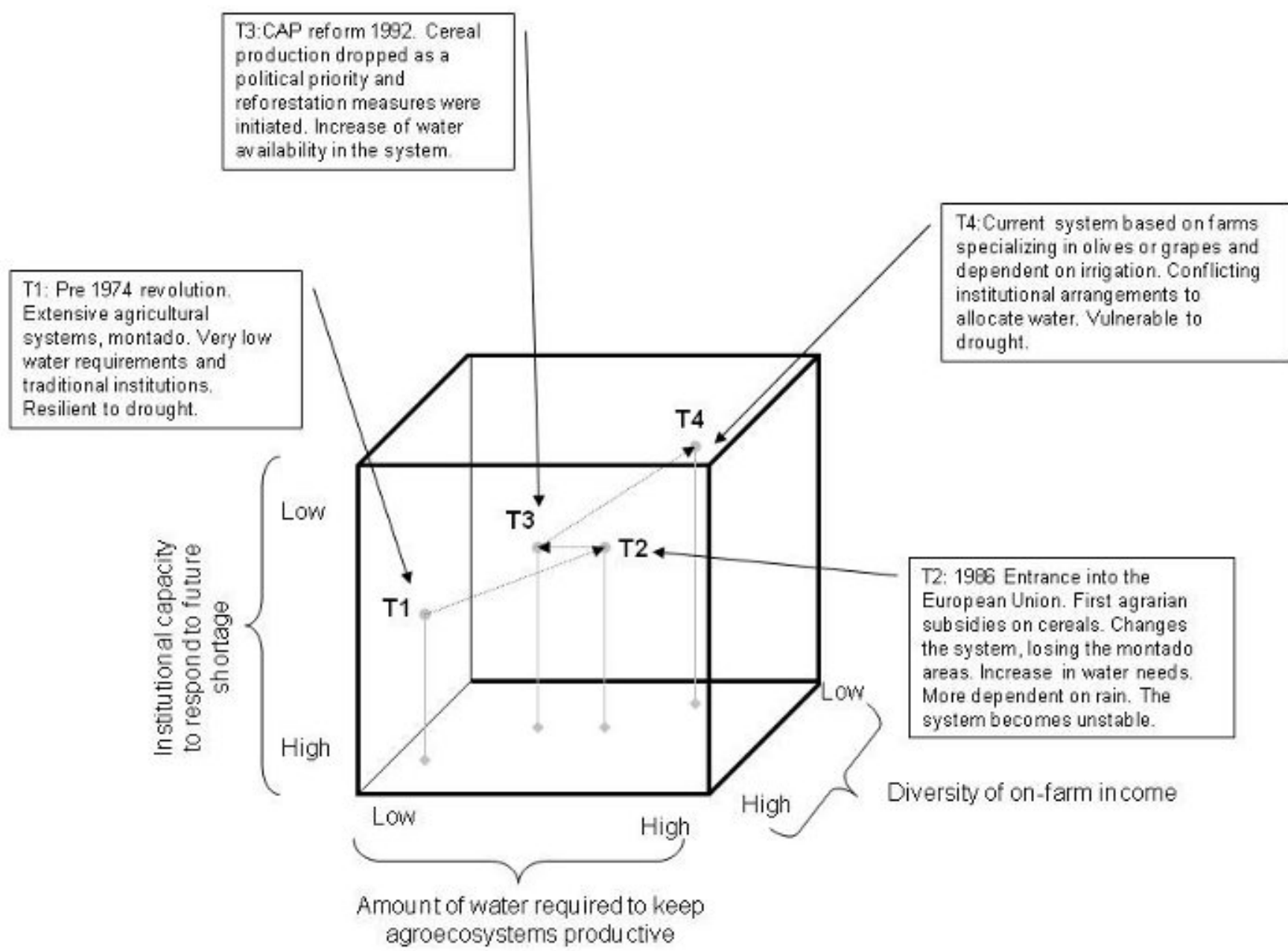

\section{Scenario 1: An Increase in Subsidies}

The first scenario (S1) explores the implications for climate vulnerability if EU subsidies for olive production increase by $10 \%$. This is widely perceived to be a likely development among those we interviewed. In the words of one stakeholder: "We expect the subsidies to rise to make the European olive market more competitive against other markets, like Arab countries or the USA." Currently, subsidies are paid in direct proportion to the annual output of olives. This means subsidies range from $<100 € /$ ha for the most traditional lowintensity farms to $>2,000 € /$ ha for the most modern, irrigated, and mechanized plantations (World
Wildlife Fund and BirdLife International 2004). Beaufoy (2003) reported that establishing irrigation on fields would result in a $530 € /$ ha gain in net returns (as opposed to $90 € /$ ha for traditional olive farming).

Based on the assumptions made in the model, a $10 \%$ increase in the olive subsidy would result in an increase in income coming from olive production and, implicitly, an increase in irrigated land, with the consequent intensification and clearing of small and nonrentable plantations (e.g., montado area). It would also result in an increase in pollution levels because more pesticides are used in this type of agriculture. This would affect water quality, which 
Fig. 7. Conceptual model for the Alentejo region showing the casual loops and interlinkages that influence the rate of change of the area converted from a montado to an irrigated system.

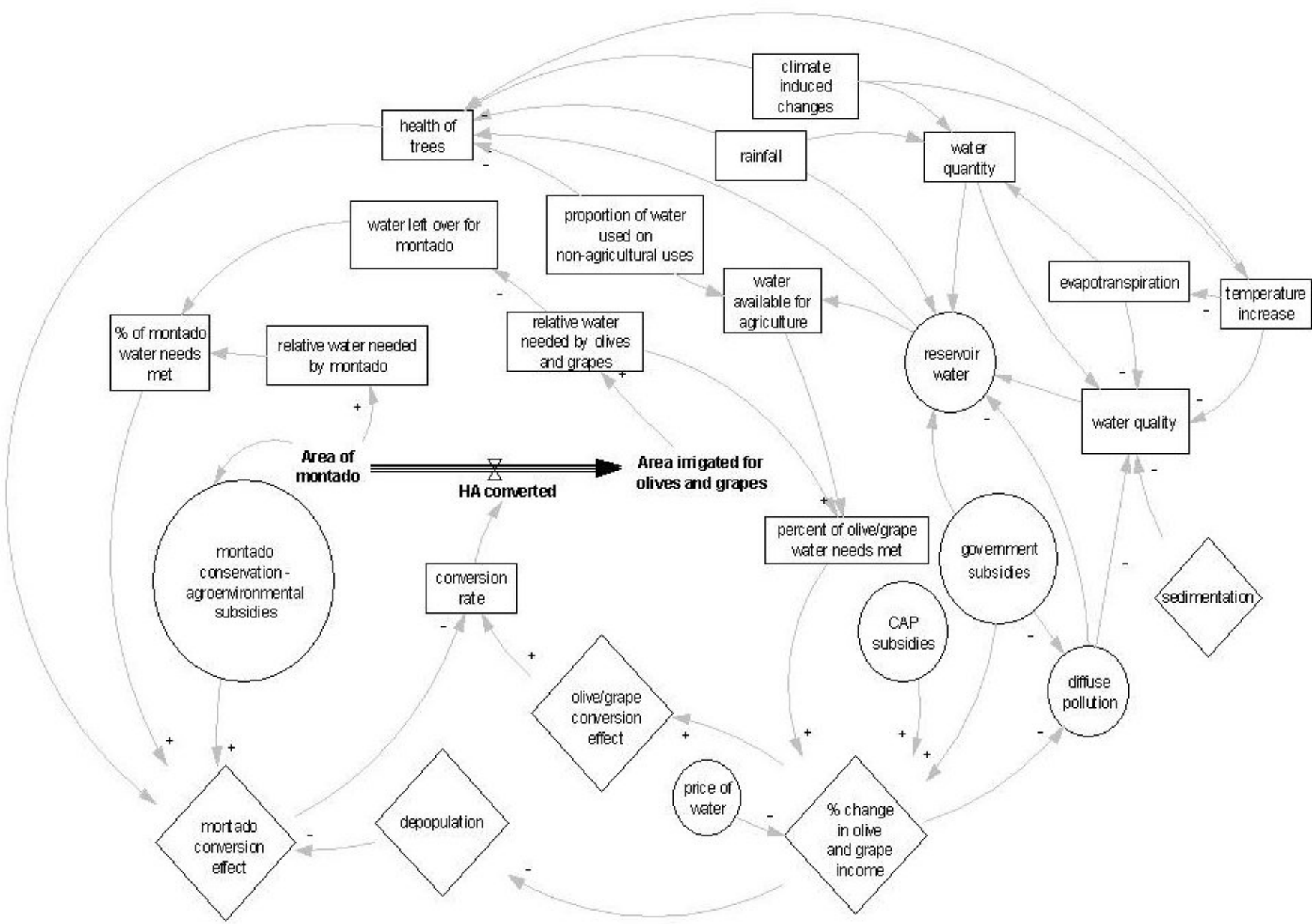

Note: Variables marked by rectangles are for indicators that refer to agroecological conditions; diamonds are used to identify socioeconomic factors, and circles refer to formal institutional factors. These three types of variables refer to the three dimensions of vulnerability outlined in the opening editorial of this special issue. "HA converted" stands for the number of ha of the montado area converted to irrigated area. The symbol (+/-) next to each arrow indicates whether the relation is positive or negative.

would in turn reduce the amount of good-quality water available for the montado and for nonagricultural uses, thus further undermining traditional agriculture in the region.

However, this scenario does suggest that, through the increase in subsidies for olive oil, the agriculture sector could enjoy relatively higher incomes than other sectors of the economy. This could slow the rate of rural depopulation. Of course, this is dependent on other economic factors, such as the opportunities for work in tourism, that fall outside the scope of this discussion. Nevertheless, and in general terms, the implications of this scenario are that overall vulnerability of the area to drought will increase if production subsidies rise, owing to the large amounts of water required for the more intensive system, the reduction in income diversity, and high subsidy dependence. The socialecological system would consequently be more vulnerable to environmental shocks. However, to explore this assessment more critically, we propose 
Fig. 8. The vulnerability space showing the historical state (T4, as in Fig. 5) and the future virtual states (S1, S2 and S3) based on the policy scenarios.

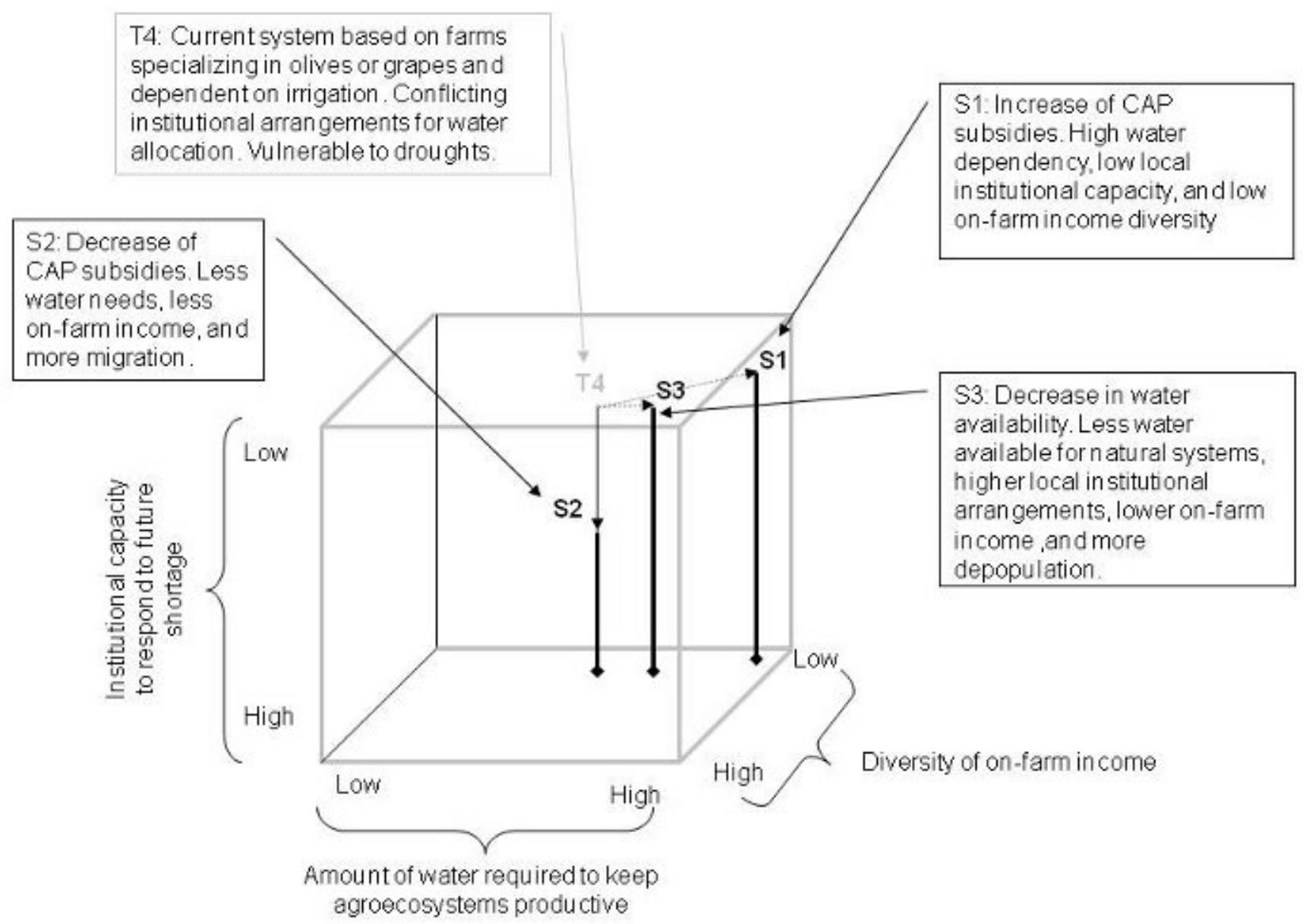

that research needs to be focused on the causal loops starting with the "CAP subsidies" part of Fig. 7 to better understand if there are links between increases in subsidies and increases climate vulnerability.

\section{Scenario 2: A Decrease in Subsidies}

Scenario two (S2) is the opposite of scenario one, and simulates the potential effect of a decrease in subsidies for olives. At the moment, olive trees are eligible for a single payment (for trees planted before 1998) as well as the production subsidy described in scenario 1. Stakeholders are concerned that this subsidy may be reduced in future. For example, one interviewee commented: "We are afraid for our future if subsidies are decreased or even stop, as happened with cereal subsidies, because the investment in the olive sector is bigger than elsewhere."

This concern is echoed by studies in other regions that show how agricultural subsidies shape land use by making some products more profitable than others (Moors et al. 2008). For instance, Amores and Contreras (2009) show that in the Andalusian region of Spain, $>60 \%$ of the olive farms would lose money were it not for the subsidies.

To explore these concerns, we ran a scenario where single payments to farmers and $50 \%$ of production subsidies are eliminated. These relations are reflected in Fig. 7 (see loop starting with "CAP 
Fig. 9. Scenarios (S1, S2, and S3)
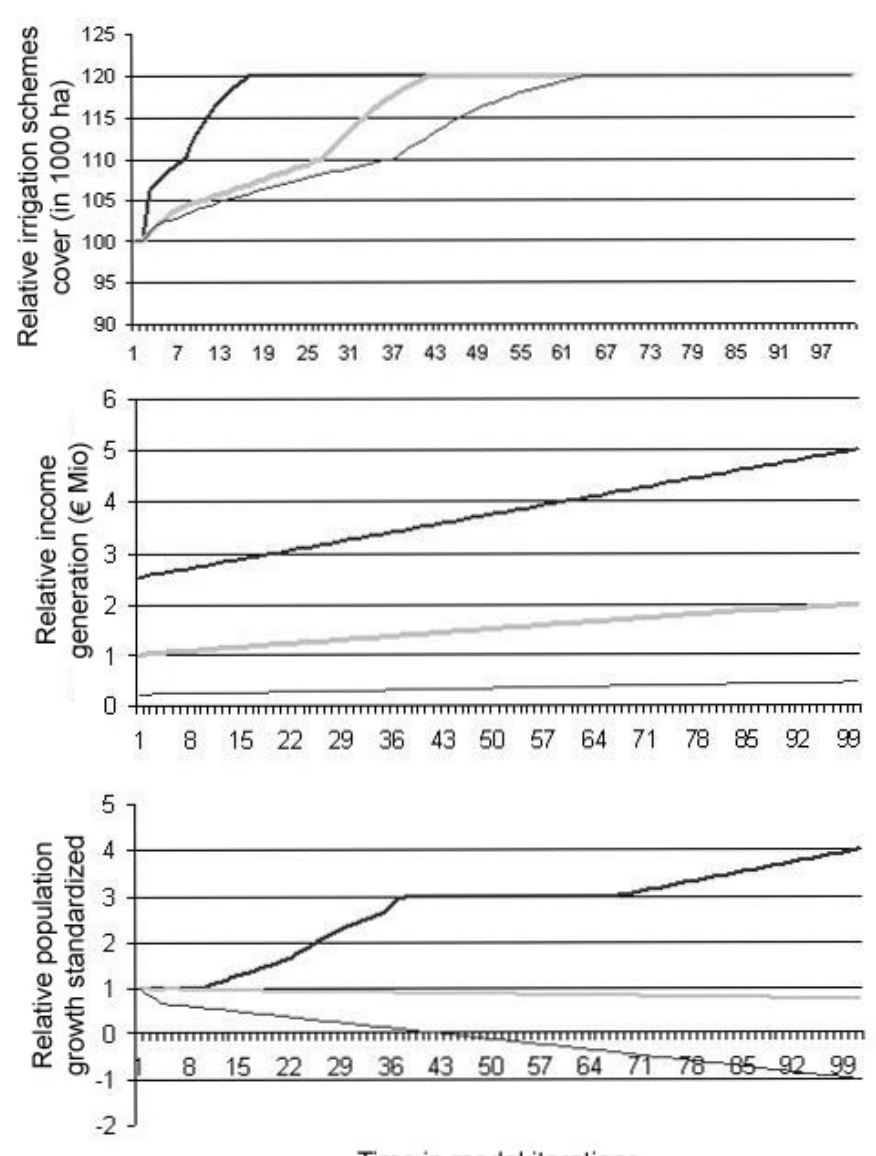

Time in model iterations

$-\mathrm{S} 1-\mathrm{S} 2-\mathrm{s} 3$
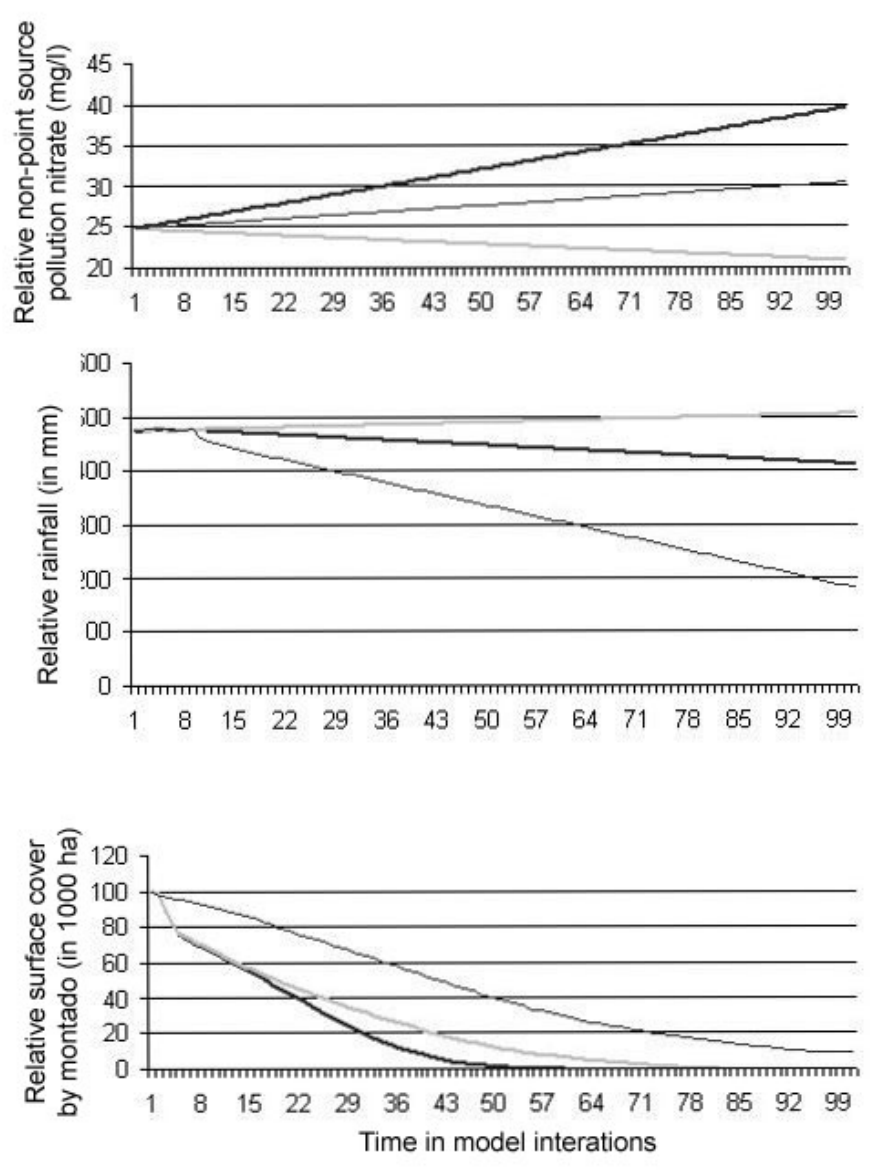

$-\mathrm{S} 1-\mathrm{S} 2-\mathrm{S} 3$ subsidies"). According to our model (see Fig. 9), the results would be a decrease in the area of irrigated land and an increase in water available for montado and nonfarm uses (see feedback loop in Fig. 7 starting with "area irrigated for olives and grapes"). This scenario shows an increase in the rate of depopulation as people leave the area to seek alternative sources of income. The rate of rural depopulation in the Alentejo is already one of the highest in Europe and is perceived as a major problem in the area by both experts (do Ó and Roxo 2001) and those interviewed.

This scenario suggests that a decrease in subsidies may reduce vulnerability to climate change in terms of agroecological factors because the increase in water available to households could be expected to reduce vulnerability. In any case, the traditional olive system produces a harvest only every second year, and consequently receives support only every two years. Therefore, the levels of income and production support from montado and the already existing irrigated land would drop, and economic indicators of vulnerability would become worse under this scenario. Further research needs to be done on the ecological and economic effects that reduced CAP subsidies might have in agricultural areas. 


\section{Scenario 3: Recurrent Droughts}

Scenario three (S3) shows the potential effect of longer and more frequent droughts on the region. For this scenario, agricultural subsidies were held constant, while rainfall variability and temperature levels were changed in line with the IPCC report, which projects a $15 \%$ drop in precipitation and an increase in temperature of $2^{\circ} \mathrm{C}$ for the period $2011-$ 2020 (Hulme and Sheard 1999, Gallego et al. 2006, Christensen et al. 2007, Pachauri and Reisinger 2007). This was seen to be an important scenario for vulnerability assessment in the Alentejo, given that over $95 \%$ of water demand in the region is for agriculture, covering $80 \%$ of the land (see description in Fig. 3). It might be expected that the impact of an increase in drought periods will be significant.

Based on this scenario, it seems that both water quality and quantity are vulnerable to climate change. Furthermore, these changes will likely reduce the water quality of the Alquera reservoir, increasing the conductivity of the stored water and making it unsuitable for agricultural, environmental, or domestic purposes. This scenario suggests that a deterioration in water quality would not be preventable (Cravo et al. 2006, Froebrich and Obermann 2006) and that it would be unlikely that the minimum water requirement for the agricultural sector would be reached (see Fig. 9). This includes the amount of rainfall needed for olive production (200 mm/yr). Consequently, results suggest that under this scenario, there would be little water left for the montado system in the future. If this coincides with the longer periods of drought projected by the Intergovernmental Panel on Climate Change, it may be that institutional arrangements such as drought plans to allocate water would need to be enhanced, and perennial crops, such as olives, will be given priority in watermanagement plans. In any case, it is expected that income diversity would drop because of yield losses.

In this simulation, the overall change in the vulnerability of the social-ecological system is less than in $\mathrm{S} 1$ and, from this, we infer that socioeconomic factors linked with changes in income will influence the system more than climate variability. However, $\mathrm{S} 3$ is consistent with $\mathrm{S} 1$ in that both show decreases in income and population. Similar to the $\mathrm{S} 2$ scenario, we assume that a smaller population implies less working power dedicated to the montado. This would lead to a higher risk of bush encroachment and the disappearance of montado areas. Therefore, we suggest further research is needed to explore the impact that climate-induced changes may have on land use (e.g., the area around the "climate-induced changes" part of Fig. 7) and to explore the ecological and economic impacts of climate predictions on subsidized agricultural and traditional systems in the region.

\section{OVERARCHING DISCUSSION}

Considering that climatic predictions project less water being available per household and farm in the Alentejo, and that reported socioeconomic changes have made this region more sensitive to droughts, the future viability of the actual social-ecological system may be in jeopardy. Nevertheless, there are many different ways that the future can unfold, and which pathway this region takes will itself be a reflection of prevailing socioeconomic and policy drivers. Here, we have shown how a holistic approach to vulnerability that uses stakeholder input to create formal dynamic models can reveal the possible (and often counterintuitive) impacts that policy and management may have on the vulnerability of the system.

The narrative suggested that there has been an overall loss in national institutional capacity to respond to droughts, an increase in on-farm specialization that makes farm incomes more sensitive to a decline in rainfall, and a shift in land use towards more water-demanding crops. Those changes may increase the economic wealth of the Alentejo in the short term, but they may also increase the region's vulnerability to future drought. Moreover, it is likely that the current key droughtmanagement policy in the region, that is, the construction of a reservoir to increase access to irrigation, has actually increased the region's vulnerability by increasing the agricultural demand for water.

By modeling different scenarios based on qualitative knowledge and numerical information, we found that vulnerability to drought may rise further. A possible exception is if subsidies for olive production are reduced. More specifically, the following key implications arise from our study (also see Table 1 and Fig. 9): 
Table 1. Comparison of scenarios results.

\begin{tabular}{lccc}
\hline \hline & & Scenarios & \\
\cline { 2 - 4 } Criteria & S1 & S2 & S3 \\
& (Increase in subsidies) & (Decrease in subsidies) & (Increase in drought) \\
\hline Income & ++ & - & - \\
Population & + & - & -- \\
Pollution & ++ & - & + \\
Water availability & - & + & -- \\
Irrigated land surface & ++ & + & - \\
Area of montado & -- & -- & - \\
\hline
\end{tabular}

1. Income: The economic viability of the Alentejo and changes in its vulnerability to drought are linked to European agricultural subsidies, and this may have an influence on maintaining the viability of different types of farming (e.g., montado). Irrigation requires a primary investment in costly technical equipment. In the short term, the change to irrigation agriculture might reduce vulnerability to drought by increasing access to water. Nevertheless, for longer lasting drought events, economic changes may mean that vulnerability increases because investments in irrigation are substantial and farmers may come to rely on the permanent availability of water and subsidies. This situation will make the region highly dependent on external factors that local institutions will have little influence over. Thus, additional research on the implications of subsidies and the Europeanization of policies is needed before policy makers can be confident that they can help to reduce long-term economic vulnerability by subsidizing specific agricultural products.

2. Population: One implication of our results is that policies designed to promote economic growth in the Alentejo may actually have a negative impact on the population size and, by implication, on the sustainability of the traditional social-ecological system that is highly labor dependent. Only S1 predicts a stable population. All three scenarios suggest that population fluctuation will harm the traditional montado system. Studies on sustainable and equitable development paths in such semiarid regions should focus on the reduction of local and "migration-triggered environmental degradation as well as vulnerability to climate change, by providing means to invest in maintenance and improvements in land while providing jobs to prevent migration to other areas" (Ribot et. al. 1996:47).

3. Pollution: This exercise suggests that water quality is an important factor affecting the vulnerability of the system. The shift to olive and vineyard cultivation has increased the quantity of pesticides used and decreased water quality. Such pollution reduces the supply of usable water, thus increasing vulnerability to drought (Rodríguez Pérez et al. 2009). Therefore, explicit investigations are needed on the ecological consequences of policies and land-use changes to avoid a decline in water quality.

4. Water availability/irrigated land: It is possible that the pressure on the available groundwater resources will increase. If 
droughts increase (as in S3), the supply of water from the reservoir will decrease. This may lead users to increase dependence on groundwater resources. The more water is used to irrigate fields, the less will be available to recharge groundwater aquifers. This suggests that the links between water requirements and production subsidies need to be better understood to avoid possible unintended consequences of policies on the social-ecological system.

5. Montados: A reduction in the montado area may occur as the economic viability of this land use declines (as shown in S1 and S3). The previously described factors of population trend, pollution, and water availability have also been shown to influence whether the montado area increases or decreases. We also question how pollution would affect the size of montado area. Further investigations of these links should take place before new policy measures are implemented.

\section{CONCLUSION}

We have assessed the vulnerability of semiarid agricultural dependent social-ecological systems to climate change in the Alentejo region of Portugal. Using a mixture of qualitative and quantitative methods, we have developed future scenarios that include the potential effect of changes to European agricultural policy. This research has facilitated our understanding of the impacts of vulnerability in the region and of the unintended consequences of policies in complex social-ecological systems.

Our assessment demonstrates that vulnerability to climate change is not only a function of bioclimatic factors; indeed, our results suggest that socioeconomic decisions could pose a greater threat than climate change in terms of increasing vulnerability to drought. Our research shows that current EU production-support subsidies for this particular region are increasing vulnerability to drought in that they encourage agricultural intensification and expansion at the expense of the more environmentally friendly and droughtresistant montado production system. However, if EU policies shift and support traditional agriculture, or stop subsidizing irrigated olive production, then this vulnerability could be reduced.
Responses to this article can be read online at: http://www.ecologyandsociety.org/volXX/issYY/artZZ/ responses/

\section{Acknowledgments:}

The work on which this contribution is based was conducted as part of the AquaStress project, funded by the European Commission under the Sixth Framework Programme (contract number 511231-2). Parts of this analysis were also funded by the UK Economics and Social Research Council's Rural Economy and Land Use Programme, and the Centre for Climate Change Economics and Policy. We thank Isabel van den Wyngaert for encouraging us to write this paper, and Elisabeth Simelton, Andrew Dougill, and Kathleen Schwerdtner Máñez for reviewing previous versions.

\section{LITERATURE CITED}

Acosta-Michlik, L. 2005. Intervulnerability assessment shifting foci from generic indices to adaptive agents in assessing vulnerability to global environmental change (a pilot project in the Philippines). Project report of the Advanced Institute on Vulnerability to Global Environmental Change. SysTem for Analysis, Research and Training (START), Washington, D.C., USA.

Adger, N. W. 1999. Social vulnerability to climate change and extremes in coastal Vietnam. World Development 27:249-269.

Adger, N. W. 2006. Vulnerability. Global Environmental Change 16:268-281.

Alcamo, J., M. B. Endejan, F. Kaspar, and T. Rösch. 2001. The GLASS model: a strategy for quantifying global environmental security. Environmental Science and Policy 4:1-12.

Amores, A. F., and I. Contreras. 2009. New approach for the assignment of new European agricultural subsidies using scores from data envelopment analysis: application to olive-growing farms in Andalusia (Spain). European Journal of Operational Research 193:718-729.

Bates, B. C., Z. W. Kundzewicz, S. Wu, and J. P. Palutikof. 2008. Climate change and water. 
Intergovernmental Panel on Climate Change (IPCC) technical paper VI. IPCC Secretariat, Geneva, Switzerland.

Beaufoy, G. 2003. The environmental impact of olive oil production in the European Union: practical options for improving the environmental impact. European Forum on Nature Conservation and Pastoralism and the Asociación para el Análisis y Reforma de la Política Agro-rural, Brussels, Belgium.

Bechtold, P., M. Kohler, T. Jung, F. Doblas-Reyes, M. Leutbecher, M. J. Rodwell, F. Vitart, and G. Balsamo. 2008. Advances in simulating atmospheric variability with the ECMWF model: from synoptic to decadal time-scales. Quarterly Journal of the Royal Meteorological Society 134:1337-1351.

Brans, J. P., C. Macharis, P. L. Kunsch, A. Chevalier, and M. Schwaninger. 1998. Combining multicriteria decision aid and system dynamics for the control of socioeconomic processes: an iterative real-time procedure. European Journal of Operational Research 109:428-441.

Brooks, N., W. Neil Adger, and P. Mick Kelly. 2005. The determinants of vulnerability and adaptive capacity at the national level and the implications for adaptation. Global Environmental Change Part A 15:151-163.

Casti, J. L.. 1997. Would-be worlds: how simulation is changing the frontiers of science. Wiley, New York, New York, USA.

Castro, M. 2008. Silvopastoral systems in Portugal: current status and future prospects. Pages 111-126 in A. Rigueiro-Rodríguez, J. McAdam, and M. R. Mosquera-Losada, editors. Agroforestry in Europe: current status and future prospects. Springer, Amsterdam, The Netherlands.

Chambel, A., J. Duque, A. Matoso, and M. Orlando. 2006. Hidrogeologia continental de Portugal. Boletín Geológico y Minero 117:163-185.

Christensen, J. H., B. Hewitson, A. Busuioc, X. Chen, I. Gao, R. Held, J. R, R. K. Kolli, W. T. Kwon, R. Laprise, L. Magana Rueda, L. O. Mearns, C. G. Menendez, J. Räisänen, A. Rinke, A. Sarr, and P. Whetton. 2007. Regional climate projections: contribution of Working Group I to the Fourth Assessment Report of the Intergovernmental Panel on Climate Change. Pages 847-943 in S. Solomon, D. Qin, M. Manning, Z. Chen, M. Marquis, K. B. Averyt, M. Tignor, and H. L. Miller, editors. Climate change 2007: the physical science basis. Cambridge University Press, Cambridge, UK.

Correia, F. N. 1993. Threatened landscape in Alentejo, Portugal: the montado and other agro silvo-pastoral systems. Landscape and Urban Planning 24:43-48.

Cravo, A., M. Madureira, H. Felícia, F. Rita, and M. J. Bebianno. 2006. Impact of outflow from the Guadiana River on the distribution of suspended particulate matter and nutrients in the adjacent coastal zone. Estuarine, Coastal and Shelf Science 70: 63-75.

Cumming, G., D. Cumming, and C. Redmann. 2006. Scale mismatches in social-ecological systems: causes, consequences, and solutions. Ecology and Society 11(1): 14. [online] URL: http: //www.ecologyandsociety.org/vol11/iss1/art14/

Department for International Development (DFID). 1995. Stakeholder participation and analysis. Social Development Division, DFID, London, UK.

do Ó, A., and M. J. Roxo. 2001. Driving forces of land use changes in Alentejo and its impacts on soil and water. Department of Geography and Regional Planning, New University of Lisbon, Lisbon, Portugal.

European Commission. 1995. The lilting lands of Alentejo. LEADER Consurtium, Agriculture Directorate, European Commission, Brussels, Belgium.

European Commission. 2005. Eurostat statistics. Eurostat, Brussels, Belgium. [online] URL: http://e pp.eurostat.ec.europa.eu/portal/page/portal/statistics/ $\underline{\text { themes }}$

Fiddaman, T. 1995. Misperceptions and mismanagement of the greenhouse effect? The simulation model. Christian Michelsen Research, Bergen, Norway.

Folke, C., L. Pritchard, F. Berkes, J. Colding, and U. Svedin. 1998. The problem of fit between ecosystems and institutions. Working paper of the International Human Dimensions Program (IHDP) on Global Environmental Change. UNU-IHDP, Bonn, Germany. 
Food and Agriculture Organization (FAO). 2007. FAOstat database. FAO, Rome, Italy. [online] URL: http://faostat.fao.org/site/377/default.aspx\#ancor

Forrester, J. W. 1961. Industrial dynamics. Massachusetts Institute for Technology (MIT), Cambridge, Massachusetts, USA.

Forrester, J. W. 2000. Policies, decisions, and information sources for modeling. Pages 51-84 in J. D. W. Morecroft, and J. D. Sterman, editors. Modeling for learning organizations. Productivity Press, New York, New York, USA.

Fraser, E. G. D. 2007. Travelling in antique lands: studying past famines to understand present vulnerabilities to climate change. Climate Change 83:495-514.

Fraser, E., A. J. Dougill, K. Hubacek, C. H. Quinn, J. Sendzimir, and M. Termansen. 2011. Assessing vulnerability to climate change in dryland livelihood systems: conceptual challenges and interdisciplinary solutions.Ecology and Society 16 (1): ZZ. [online] URL: http://www.ecologyandsociety. org/vol16/iss 1/artZZ/

Froebrich, J., and M. Obermann. 2006. Contribution to an overview publication for the characterization of water stress mitigation options: AquaStress Project. Leibnitz University, Hannover, Germany.

Gallego, M. C., J. A. García, J. M. Vaquero, and V. L. Mateos. 2006. Changes in frequency and intensity of daily precipitation over the Iberian Peninsula. Journal of Geophysical Research 111: D24105.

Gouveia, C., R. M. Trigo, and C. C. Da Camara. 2009. Drought and vegetation stress monitoring in Portugal using satellite data. Natural Hazards and Earth Science. 9:185-195.

Government of Portugal. 2001. Plano de Bacia Hidrográfica do Rio Guadiana (PGRBP). Institute for Water (INAG), Ministry of the Environment and Land Use Planning (MAOT), Lisbon, Portugal.

Heitzmann, K., R. S. Canagarajah, and P. B. Siegel. 2002. Guidelines for assessing the sources of risk and vulnerability. Social protection discussion paper series. Social Protection Unit, Human Development Network, World Bank, Washington, D.C., USA.
Howlett, D., R. Bond, P. Woodhouse, and D. Rigby. 2000. Stakeholder analysis and local identification of indicators of the success and sustainability of farming based livelihood systems. Working paper: sustainability indicators for natural resource management and policy. Research Project No. R7076CA. DFID, London, UK.

Hulme, M., and N. Sheard. 1999. Climate change scenarios for the Iberian peninsula. Climate Research Unit, Norwich, UK.

Hurd, B., N. Leary, R. Jones, and J. Smith. 1999. Relative regional vulnerability of water resources to climate change. Journal of the American Water Resources Association 35:1399-1409.

Kinzig, A. P., P. Ryan, M. Etienne, H. Allison, T. Elmqvist, and B. H. Walter. 2006. Resilience and regime shifts: assessing cascading effects. Ecology and Society 11(1): 20. [online] URL: http://www.e cologyandsociety.org/vol11/iss1/art20/

Kosmas, C., and I. Valsamis. 2002. Deliverable 1.3a: driving forces and pressure indicators: decision making by local stakeholders. Combatting desertification in the Mediterranean Europe: linking science with stakeholders. Report to DESERTLINKS, Fifth Framework Programme of the European Commission. King's College, London, UK.

Martínez Fernández, J., and M. A. Esteve Selma. 2004. The dynamics of water scarcity on irrigated landscapes: Mazarrón and Aguilas in south-eastern Spain. System Dynamics Review 20:117-137.

Montgomery, R. 1995. Short guidance notes on how to do stakeholder analysis of aid projects and programmes. Resources in Social Development Practice. Centre for Development Studies, Swansea University, Swansea, Wales.

Moors, E., I. Van den Wyngaert, M. Máñez Costa, M. Bauer, I. David, P. Koundouri, and K. Tarnacki. 2008. D2.2.4: report on regional vulnerability (in different sectors) for water. Report to Aquastress, Sixth Framework Programme of the European Commission.

Moss, R. H., A. Brenkert, and E. Malone. 2000. Measuring vulnerability: a trial indicator set. Pacific Northwest National Laboratory (PNNL), U. S. Department of Energy, Richland, Washington, USA. 
Nordhaus, W. 1992. An optimal transition path for controlling greenhouse gases. Science 258:13151319.

Nunes, J., J. Andrade, F. Abreu, L. Gazarani, and M. Madeira. 2009. The Montado agroforestry system microclimatic specificity in the context of global change. International Scientific Conference: Sustainable Development and Bioclimate: Human Activities in the Context of Bioclimate Factors. 58 October, 2009, Stará Lesná, Slovakia.

O’Brien, R. M., and K. L. Leichenko. 2000. Double exposure: assessing the impacts of climate change within the context of economic globalization. Global Environmental Change 10:221-232.

Ostrom, E. 1990. Governing the commons: the evolution of institutions for collective action. Cambridge University Press, Cambridge, UK.

Pachauri, R. K., and A. Reisinger, editors. 2007. Contribution of Working Groups I, II and III to the Fourth Assessment Report of the Intergovernmental Panel on Climate Change. IPCC, Geneva, Switzerland.

Paredes, D., R. M. Trigo, R. Garcia-Herrera, and I. F. Trigo. 2006. Understanding precipitation changes in Iberia in early spring: weather typing and storm tracking approaches. Journal of Hydrometeorology 7:101-113.

Pereira, P. M., and M. Pires de Fonseca. 2003. Nature versus nurture: the making of the montado ecosystem. Conservation Ecology 7(3): 7. [online] URL: http://www.consecol.org/vol7/iss3/art7/.

Pimenta, M. T., M. J. Santos, and R. Rodrigues. 1997. A proposal of indices to identify desertification prone areas. Jornadas de reflexión sobre el Anexo IV de aplicación para el Mediterráneo Norte, 22-23 May 1997, Murcia, Spain. Convention to Combat Desertification (CCD) Portugal and INAG, MAOT, Lisbon, Portugal.

Pinto-Correia, T. 1993. Threatened landscape in Alentejo, Portugal: the "montado" and other "agrosilvo-pastoral" systems. Landscape and Urban Planning 24:95-106.
Pinto-Correia, T., B. Breman, I. L. Ramos, and A. van Doorn. 2004. Dealing with land abandonment: the challenge of policy intervention in marginal rural areas. Examples from a municipality in southeastern Portugal. Cemagref Colloquium Paper. Montpellier and Paris, France.

Pinto-Correia, T., and J. Mascarenhas. 1999. Contribution to the extensification/intensification debate: new trends in the Portuguese montado. Landscape and Urban Planning 46:125-131.

Polsky, C., D. Schröter, S. Gaffin, M. L. Martello, R. Neff, A. Pulsipher, and H. Selin. 2003. Assessing vulnerabilities to the effects of global change: an eight-step approach. Belfer Center for Science and International Affairs, Cambridge, Massachusetts, USA.

Ribot, J. C., A. R. Magalhães, and S. S. Panagides. 1996. Climate variability, climate change and social vulnerability in the semi-arid tropics. Cambridge University Press, Cambridge, UK.

Rodríguez Pérez, J., S. Loureiro, S. Menezes, P. Palma, R. M. Fernandes, I. R. Barbosa, and A. M. V. M. Soares. 2009. Assessment of water quality in the Alqueva reservoir (Portugal) using bioassays. Environmental Science and Pollution Research. 17 (3):688-702.

Rodwell, M. J., and F. J. Doblas-Reyes. 2006. Medium-range, monthly, and seasonal prediction for Europe and the use of forecast information. Journal of Climate 19:6025-6046.

Seita-Coelho, I. 2006. The Guadiana basin (Portugal): natural resources, agriculture and agricultural development. International Seminar on Sustainable Development Policies in the Mediterranean Countries in the Context of the EU's Neighbourhood Policies 2007-2013. 8-9 February 2006, Cairo, Egypt.

Seixas, J. 2000. Assessing heterogeneity from remote sensing images: the case of desertification in southern Portugal. International Journal of Remote Sensing 21:2645-2663.

Semenov, M. A., and F. J. Doblas-Reyes. 2007. Utility of dynamical seasonal forecasts in predicting crop yield. Climate Research 34:71-81. 
Simelton, E., E. Fraser, M. Termansen, P. Foster, and A. J. Dougill. 2009. Typologies of crop-drought vulnerability: an empirical analysis of the socioeconomic factors that influence the sensitivity and resilience to drought of three major food crops in China (1961-2001). Environmental Science and Policy 12:438-452.

Smit, B., and J. Wandel. 2006. Adaptation, adaptive capacity and vulnerability. Global Environmental Change 16282-:292.

Stave, K. 2002. Using system dynamics to improve public participation in environmental decisions. System Dynamics Review 18:139-167.

Sullivan, C. A., J. R. Meigh, and T. S. Fediw. 2002. Final report: derivation and testing of the water poverty index phase 1. Centre for Ecology and Hydrology, Oxfordshire, UK.

Trigo, R. M., and C. C. Da Camara. 2000. Circulation weather types and their influence on the precipitation regime in Portugal. International Journal of Climatology 20:1559-1581.

Turner II, B. L., R. Kasperson, P. A. Matson, J. J. McCarthy, R. W. Corell, L. Christensen, N. Eckley, J. X. Kasperson, A. Luers, M. L. Martello, C. Polsky, A. Pulsipher, and A. Schiller. 2003. A framework for vulnerability analysis in sustainability science. Proceedings of the National Academy of Sciences 100:8074-8079.

United Nations Educational, Scientific and Cultural Organization (UNESCO). 2006. Ecohydrology demonstration projects. International Hydrological Programme, UNESCO, Paris, France. [online] URL: http://www.unesco.org/water/ihp/ecohydrology/ demos/guadiana.shtml.

Van den Wyngaert, I. 2006. D2.2-2: State of water stress in different sectors in the test site areas and current strategies to cope with water stress. Report to Aquastress, Sixth Framework Programme of the European Commission.

Vörösmarty, C. J., P. Green, J. Salisbury, and R. B. Lammers. 2000. Global water resources: vulnerability from climate change and population growth. Science 289:284-288.

World Wildlife Fund (WWF) and BirdLife International. 2004. EU policies for olive farming: towards sustainable production in Europe. WWF and BirdLife International, Brussels, Belgium. 


\section{APPENDIX 1. Information on the Alentejo region, Portugal.}

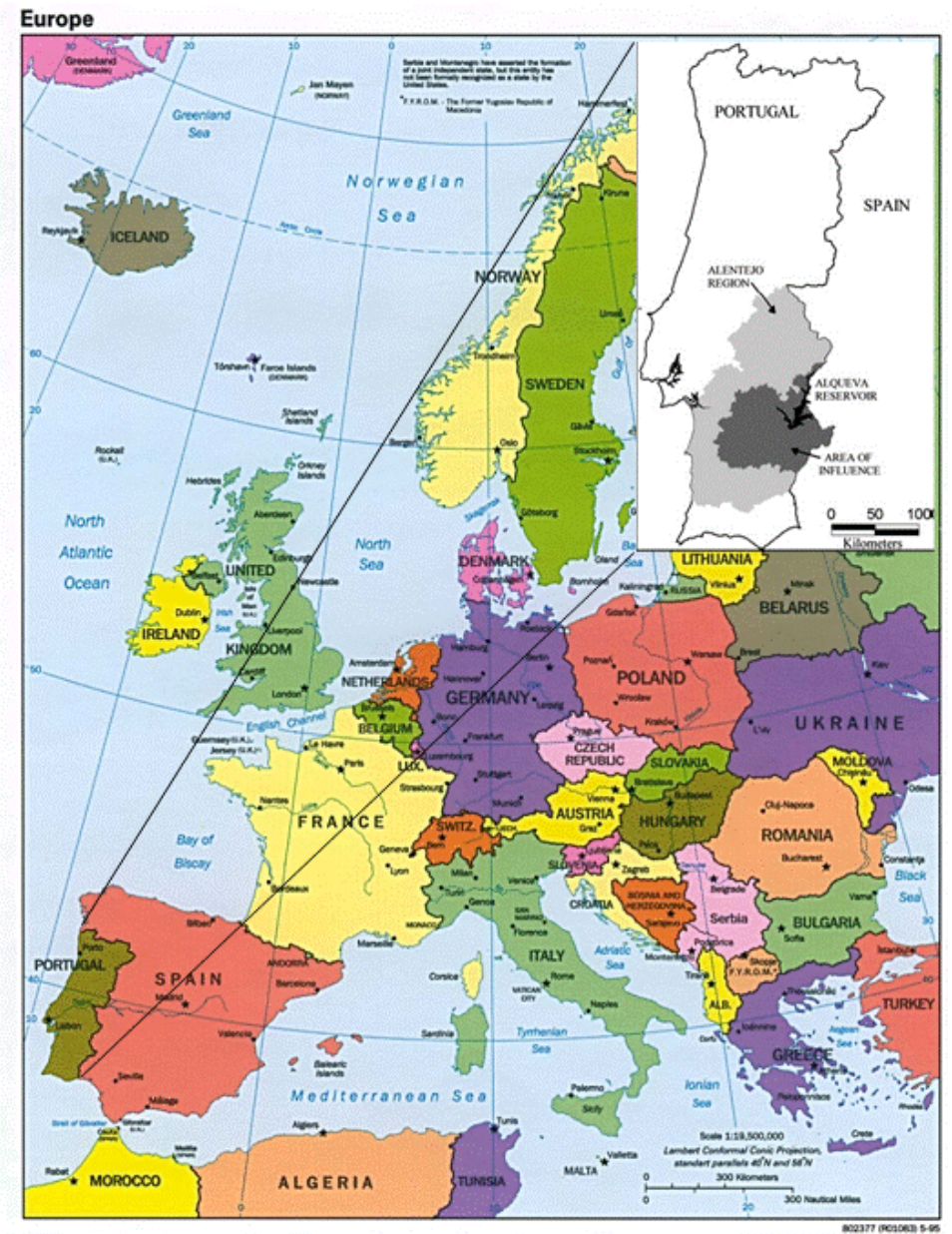

In the Alentejo region (see Fig. 2), soils are generally poor and thin with an impermeable surface that leads to high levels of surface run-off due to steep slopes. The soils are well adapted to supporting shrub and tree species such as Cistus spp. and Quercus spo. (do Ó and Roxo 2001). The traditional farming system is rainfed, and combines raising cattle and small stock with cereal cultivation in so-called "montado" systems. These montado systems are typified by sparse holm trees (or cork oaks) combined with a rotation of dry cereal cultivation, pasture and fallow in the understorey (Pinto-Correia et al. 2004). The biodiversity of the traditional montado system is very high, owing to the rotation among different land uses and to low grazing densities (Pinto-Correia and Mascarenhas 1999b).

The region has a typically Mediterranean climate that is characterized by annual precipitation ranging from 400 to 600 $\mathrm{mm}$, concentrated between October and $\mathrm{M}$ ay, and hot, dry summers. This is changing: since the $1970 \mathrm{~s}$, precipitation in March has decreased by $37.5 \%$; there has been an increase in heavy rains in periods of the year when vegetation cover is sparse, often coinciding with land being tilled; and there has been a decline in the number of total rainfall events each year (Paredeset al. 2006). An increase in severe drought periods has also been reported. In 2005, drought measures such as water restrictions for yearly crops began to be implemented in March instead of June, as happens in normal years (Trigo and Da Camara 2000, do 0 and Roxo 2001, Paredes et al. 2006). The increase in rainfall intensity and the prolonged periods of drought have contributed to serious soil erosion; $25 \%$ of the region is now classified as "affected by desertification" and a further $45 \%$ has a "high sensitivity to desertification" (do $\hat{O}$ and Roxo 2001). 
APPENDIX 2. List of regional stakeholders interviewed.

Stakeholders interviewed include representatives of the:

- Pig Farmers' Association, Ourique

- Farmers' Association of Inner Alentejo, Beja

- Farmers' Association of Serpa Municipalities (AACS)

- Federation of Farmers Associations (FAABA), Beja

- Association of Water Users and Beneficiaries of Odivelas Reservoir for Irrigation Purposes, Ferreira do Alentejo

- Association of Water Users and Beneficiaries of Caia Reservoir for Irrigation Purposes, Elvas

- Irrigation Research Center (COTR), Beja

- Regional Development Authorities (CCDRs) of the Alentejo and the Algarve

- National Water Institute (INAG)

- Agricultural and Hydraulic Development Institute (IDHRA), Lisbon

- Winery Commission of the Alentejo (CVRA)

- Olive oil producers in the Alentejo

- Municipalities Association of the Left Bank of the Guadiana

- Enterprise for Development and Infrastructure (EDIA) of the Alqueva

- Public-sector water suppliers in the North Alentejo and Central Alentejo Water Utility (Aguas do Alentejo)

- Public-sector water suppliers in the Algarve region (Aguas do Algarve)

- Commission for the Environmental Observation of the AlquevaDam (CAIA)

- Centre for Environmental Law and Sustainable Development (EURONATURA)

- League for the Protection of Nature

- National Natural Park "Guadiana" Park Authorities, Mertola

- Ministry of Environment, Regional Development and Planning, Lisbon

- National Institute for Nature Conservation (ICN)

- QUERCUS

- Commission for the Application and Development of the Albufeira Convention (CADC; between Spain and Portugal), Lisbon

- Energy sector, Lisbon 
APPENDIX 3. Internal, local, and government sources used for secondary data collection.

Apostolaki, S., and D. Assimacopoulos. 2006. Aquastress: mitigation of water stress through new approaches to integrating management, technical, economic and institutional instruments. Deliverable D1.2-1. Data on pressures and water availability. NTUA.

Carrapi, F., M. H. Costa, M. L. Costa, G. Teixeira, A. A. Frazao, M. C. R. Santos, and M. V. Baiao. 1996. The uncontrolled growth of Azolla in the Guadiana River. Aquaphyte Online. online [URL]: http://aquat1.ifas.ufl.edu/aq-w9 16.html.

Instituto da Água (INAG). 2000. Qualidade da água. online [URL]:

http://snirh.inag.pt/snirh/dados sintese/qual ag anual/qag anuario.html.

INAG. 2003. Preliminary lessons resulting from guidance documents testing in pilot river basins. Direcção de Serviços de Recursos Hidricos (DSRH) do INAG.

INAG. 2005. Relatório sintese sobre a caracterização das regiões hidrográficas prevista na Directiva-Quadro da Água. Ministério do Ambiente, do Ordenamento do Território e do Desenvolvimento regional.

INAG. 2005b. Caracterizacao de bacias drenantes de barragens. online [URL]: http://snirh.inag.pt/cgi-bin/inv barragens/portugues/albuf_princ.tcl.

INAG/DSRH. 2002. Bacia do Guadiana (aplicação da DQA), galleria de imagens. online [URL]: http://snirh.inag.pt/snirh/atlas/portugues/docs/atlas agua.php?galeria=3.

Instituto de Meteorogia. Anuário Climatológico de Portugal. online [URL]: http://www.meteo.pt/pt/produtosservicos/catalogo de publicacoes/anuario.clima/index.htm.

Ministéro de Ambiente e Ordenamento do Território. 2000. Volume I-Síntese da análise e diagnóstico da situação actual; PBH do Rio Guadiana.

Ministério do Ambiente e Ordenamento do Território. 2001. Portuguese Guadiana river basin plan (Plano de bacia hidrográfica do rio Guadiana).

Olay, A., N. Gomes, R. Álvarez, S. Sousa, J. Loredo, and M. A. Estrela. 2004. Interaction between climatic conditions and water pollution: a case study from the transboundary catchment of Guadiana river. Transcat conference paper.

Pinheiro, A. , M. L. Carvalho, M. J. Parreira, and J. Saraiva. 2001. Survey of institutional frameworks for water management in European irrigated systems: Portugal. WADI project Deliverable 1, European Commission Fifth Framework Programme contract EWK1-200000057.

Projecto Ersa - Estudos dos Recursos Hidricos Subterraneos do Alentejo. Coordenaçao Lina Maria Branco de Freitas Jan. Commisao de Coordenaçao da Regiao Alentejo. ISBN - 972-644-108-0.

Climate Change Impacts, Mitigation and Adaptation Research Group. 1999. Climate change in Portugal: scenarios, impacts and adaptation. online [URL]: http://www.siam.fc.ul.pt/siam.html.

WaterStrategyMan. 2002. The range of existing circumstances. EU funded project EVK1CT-2001-00098; Deliverable D1, European Commission Fifth Framework Programme, RuhrUniversity Bochum. online [URL]: http://environ.chemeng.ntua.gr/wsm/. 